\section{Covering the territory: can Injury Prevention do better?}

\author{
Roderick J McClure
}

The field of injury prevention has long struggled with the 'splitting versus clumping' dilemma. The most obvious example of this is our highlighting the burden of the injury as a whole (which is ever so much more a compelling figure than the burden of any of its components), and then addressing that burden by focusing, necessarily, on its component parts. A close look at the cause, and body part-injured codes in the International Classification of Diseases (ICD) ${ }^{1}$ shows the extent to which efforts to reduce the burden of injury can be fragmented.

However, the ICD classification goes only part way towards mapping the full range of specifics that fall within our territory. Information about individual injuries can be aggregated at the community, national or global levels but the specific aspects of each injury occurrence needs somehow to be captured. A range of scientific methods are used to do this. Once identified, interventions to redress the causes need to be developed for each of the injury categories using contextual information available. Each of these interventions requires scientific validation. A range of scientific methods are used to do this.

Injury Prevention is a platform for making injury prevention information available in a way that supports use of this information for the local and global reduction of injury-related harm. In this issue of Injury Prevention, we publish 16 manuscripts that were next in the queue. While only a small sample of what is submitted, they are suggestive of what we are publishing at the moment.

The units of organisation of the corresponding authors of these 16 manuscripts are located in India, USA, Canada,

Correspondence to Dr Roderick J McClure, School of Rural Medicine, University of New England, Armidale, NSW 2350, Australia; rmcclure@une.edu.au
Australia, Greece, Taiwan, South Africa and Uganda. Within the manuscript list is a study of injury in First Nations people and a study using information from 89 countries. The research topics are equally distributed across drowning, violence/ suicide, sport, road safety, prescription and other drugs. The large majority of the manuscripts describe epidemiological (descriptive and analytical) studies, with the remainder being intervention evaluations, commentaries and reviews. All manuscripts are of the same format as those published in the very first issue of Injury Prevention

Despite this issue's breadth and depth, I am still not sure that at sixteen manuscripts per issue, the journal will ever be able to cover the territory. Should we be publishing not 'more and broader', but 'less and more concise'? Should we be publishing a radically different type of paper that is more relevant to the Journal's purpose.. Can we rethink the way the Journal delivers on its goals.

Injury Prevention has a submission category State of the Art Reviews (SOTARS). These reviews synthesise information from across world in a manner that facilitates immediate adoption. SOTARs have a word limit of 3500 words and the following structure: Title: Concisely stating the topic of the SOTAR; Introduction: Providing well referenced reasons for why the topic is important; Critical issues: Presenting the specific topical or problematic elements of the topic that make the topic critical, followed by a well referenced summary of the evidence (for/against/or otherwise) for each critical issue; Gaps in the literature: Indicating where more work needs to be done; Recommendations for practice: Explaining how current evidence can be applied in prevention practice; Future directions for researchers: Encouraging more work in the specific aspects of the topic likely to achieve best results.

I would encourage anyone wishing to prepare a SOTAR for submission to contact one of the SOTAR editors and discuss ideas. I would encourage anyone with ideas about how Injury Prevention can better cover the territory to discuss these with an editorial board member. Doing better may mean completely reshaping the way Injury Prevention reports the injury prevention science you are all undertaking.

Funding The authors have not declared a specific grant for this research from any funding agency in the public, commercial or not-for-profit sectors.

Competing interests None declared.

Patient and public involvement Patients and/or the public were not involved in the design, or conduct, or reporting, or dissemination plans of this research.

Patient consent for publication Not required.

Provenance and peer review Not commissioned; internally peer reviewed.

\section{(อ) OPEN ACCESS}

Open access This is an open access article distributed in accordance with the Creative Commons Attribution Non Commercial (CC BY-NC 4.0) license, which permits others to distribute, remix, adapt, build upon this work non-commercially, and license their derivative works on different terms, provided the original work is properly cited, appropriate credit is given, any changes made indicated, and the use is non-commercial. See: http:// creativecommons.org/licenses/by-nc/4.0/.

(C) Author(s) (or their employer(s)) 2021. Re-use permitted under CC BY-NC. No commercial re-use. See rights and permissions. Published by BMJ.

$$
\text { A) Check for updates }
$$

To cite McClure RJ. Inj Prev 2021;27:299.

Inj Prev 2021;27:299.

doi:10.1136/injuryprev-2021-044347

\section{ORCID iD}

Roderick J McClure http://orcid.org/0000-0002-90678282

\section{REFERENCE}

1 WHO. International statistical classification of diseases and related health problems (ICD). Available: https:// www.who.int/standards/classifications/classification-ofdiseases [Accessed 1 Jul 2021]. 